\title{
Long-term performance of a plant microbial fuel cell with Spartina anglica
}

\author{
Ruud A. Timmers $\cdot$ David P. B. T. B. Strik • \\ Hubertus V. M. Hamelers • Cees J. N. Buisman
}

Received: 23 September 2009/Revised: 21 December 2009/Accepted: 4 January 2010/Published online: 2 February 2010

(C) The Author(s) 2010. This article is published with open access at Springerlink.com

\begin{abstract}
The plant microbial fuel cell is a sustainable and renewable way of electricity production. The plant is integrated in the anode of the microbial fuel cell which consists of a bed of graphite granules. In the anode, organic compounds deposited by plant roots are oxidized by electrochemically active bacteria. In this research, salt marsh species Spartina anglica generated current for up to 119 days in a plant microbial fuel cell. Maximum power production was $100 \mathrm{~mW} \mathrm{~m}^{-2}$ geometric anode area, highest reported power output for a plant microbial fuel cell. Cathode overpotential was the main potential loss in the period of oxygen reduction due to slow oxygen reduction kinetics at the cathode. Ferricyanide reduction improved the kinetics at the cathode and increased current generation with a maximum of $254 \%$. In the period of ferricyanide reduction, the main potential loss was transport loss. This research shows potential application of microbial fuel cell technology in salt marshes for bio-energy production with the plant microbial fuel cell.
\end{abstract}

Keywords Plant microbial fuel cell · Rhizodeposition .

Bio-energy $\cdot$ Spartina anglica $\cdot$ Potential losses .

Green electricity

\section{Introduction}

Nowadays, the need for sustainable renewable energy is urgent due to depletion of fossil fuels, increasing energy

R. A. Timmers • D. P. B. T. B. Strik • H. V. M. Hamelers $(\bowtie) \cdot$

C. J. N. Buisman

Sub-department of Environmental Technology,

Wageningen University,

Bomenweg 2, P.O. Box 8129, Wageningen, The Netherlands

e-mail: bert.hamelers@wur.nl consumption, climate change, and environmental pollution. Current production processes for bio-energy such as bioethanol or biodiesel often compete with food production. Competition with food production not only increases food prices and malnourishment (Pimentel et al. 2009) but also increases incentives for deforestation by claiming land for food production or bio-energy crops. Deforestation is the second most important source of greenhouse gas emissions in the world (von Witzke 2008). Therefore, to have sustainable renewable energy, there should be no competition with food production. In search for renewable and sustainable bio-energy production, Strik et al. (2008) presented the plant microbial fuel cell (P-MFC). The P-MFC harvests solar energy as electricity by combination of electricity generation by bacteria through oxidation of organic compounds and deposition of organic compounds by plants into the rhizosphere. The aim of the P-MFC is to transform solar energy into electrical energy through oxidation of rhizodeposits by electrochemically active bacteria. Potential electrical output without crop harvesting is $5,800 \mathrm{kWh} \mathrm{ha}^{-1}$ year $^{-1}$ (Strik et al. 2008), comparable to conventional renewable bio-energy sources with crop harvesting.

De Schamphelaire et al. (2008) presented the sediment type P-MFC which consisted of an anode and cathode without membrane separation. The P-MFC as described by Strik et al. (2008) consisted of an anode and cathode separated by a membrane. In the anode, electrochemically active bacteria oxidize rhizodeposits whereby electrons, protons, and $\mathrm{CO}_{2}$ are produced. Electrons and protons are transferred to the cathode compartment; $\mathrm{CO}_{2}$ escapes to the atmosphere where it can be used again by plants for photosynthesis. At the cathode electrons, protons, and oxygen are consumed by reduction of oxygen to water. Production and consumption of electrons results in a 
potential difference between anode and cathode which makes electrons flow through the electrical circuit.

To avoid competition with agricultural food production, salt marsh species should be tested in the P-MFC, because there is no competition for arable land (Galvani 2007). Until now no salt marsh species was tested in the P-MFC. Furthermore, there is no literature describing biochemical conditions and potential losses in the P-MFC.

The first objective is to prove long-term electricity generation by Spartina anglica in the P-MFC. The second objective is to gain insight in potential losses of the P-MFC as well as biochemical conditions in the anode compartment. To meet both objectives, the $S$. anglica P-MFC was monitored for a period equal to the length of one growth season. One growth season is defined as the period $S$. anglica is able to photosynthesize, which is at temperatures above $7{ }^{\circ} \mathrm{C}$ (Gray et al. 1991), in the Netherlands in 2008 from mid March to mid November (around 240 days). In this period cell potential, cathode potential, anode potential, membrane potential, $\mathrm{pH}$, and conductivity of the P-MFC were monitored.

\section{Material and methods}

\section{Experimental set-up}

The P-MFC consisted of a cathode and an anode separated by a membrane. The cathode consisted of graphite felt in a beaker. The anode consisted of graphite granules in a glass cylinder in which $S$. anglica was planted, and a membrane at the bottom of the glass cylinder. The anode was placed with the membrane on the graphite felt in the cathode and the PMFC was formed. Strik et al. (2008) described the P-MFC in detail. The current collector was different, here the current collector was a golden wire glued to a Teflon-coated copper wire placed in the anode as well as the cathode. To close the electrical circuit, current collectors were connected over an external resistance of $1,000 \Omega$.

The P-MFCs were placed in a cabinet of which both front and back were open. In the cabinet temperature fluctuated between $23-27{ }^{\circ} \mathrm{C}$, humidity was uncontrolled, light intensity in the photosynthetic active region was $261 \pm$ $56 \mu$ mole $\mathrm{m}^{-2} \mathrm{~s}^{-1}$, and illumination period was $14 \mathrm{~h}_{\text {day }}{ }^{-1}$. To provide illumination, metal-halogen lamps (two of $250 \mathrm{~W}$ and two of $400 \mathrm{~W}$ Spacesaver) were used. On day 154, P-MFCs were moved into a climate control cabinet (Microclima 1750 Snijders). In the climate control cabinet temperature was $25^{\circ} \mathrm{C}$, humidity was $75 \%$, light intensity in the photosynthetic active region was $248 \pm 44 \mu$ mole $\mathrm{m}^{-2}$ $\mathrm{s}^{-1}$, and illumination period was $14 \mathrm{~h} \mathrm{day}^{-1}$. On day 168 , light intensity in the photosynthetic active region was increased to $596 \pm 161 \mu$ mole $\mathrm{m}^{-2} \mathrm{~s}^{-1}$.
Preparation of graphite granules

Graphite granules with a diameter of 1 to $2 \mathrm{~mm}$ (le Carbone, Wemmel Belgium) were used as electrode material in the anode. An acetate fed P-MFC was used to grow electrochemical active biofilm on graphite granules. To grow electrochemical active biofilm the plant was left out and the top of the P-MFC was closed with a screw cap. Anolyte solution was Modified Hoagland solution buffered with $8 \mathrm{mM}$ phosphate buffer ( $\mathrm{pH}$ 7.0). Substrate was $20 \mathrm{~mL} \mathrm{~L}^{-1}$ of $2 \mathrm{M}$ potassium acetate added after the anolyte solution was flushed with nitrogen gas for $15 \mathrm{~min}$. Catholyte was a $50 \mathrm{mM}$ potassium ferricyanide $\left(\mathrm{K}_{3} \mathrm{FeCN}_{6}\right)$ solution buffered with $8 \mathrm{mM}$ phosphate buffer (pH 7.0). To both anolyte and catolyte $20 \mathrm{~g} \mathrm{~L}^{-1}$ sodium chloride and $5 \mathrm{~g} \mathrm{~L}^{-1}$ magnesium chloride was added to reach the conductivity of the pore water solution of the soil on which $S$. anglica was grown $\left(47 \mathrm{mS} \mathrm{cm}^{-1}\right)$. Each acetate fed P-MFC was inoculated with $20 \mathrm{~mL}$ of anolyte of a potassium acetate fed flat plate microbial fuel cell (conductivity $4.98 \mathrm{mS} \mathrm{cm}^{-1}$ ), which was inoculated with sediment harvested in July 2007 at GPS coordinates N58.04.00 G011.33.50, containing $27 \mathrm{~g} \mathrm{~L}^{-1} \mathrm{NaCl}$. The electrochemically active biofilm was grown for 39 days in the acetate fed P-MFC of which the anolyte was refreshed at day 18 .

\section{P-MFC operation}

Four P-MFCs, two blanks (P-MFCs without plant) and two duplicates (P-MFC1 and P-MFC2), were used. In P-MFC1 and P-MFC2, one clump with two or three stems (fresh weight 8.0 to $15.0 \mathrm{~g}$ ) of $S$. anglica was planted in $165 \mathrm{~g}$ of prepared graphite granules in the anode. S. anglica was harvested in July 2007 at GPS coordinates N51.67.654 G004.13.656 where soil pore water conductivity was $47 \mathrm{mS} \mathrm{cm}{ }^{-1}$. Until October 2007, S. anglica was grown indoors under artificial illumination.

Anolyte was 1/2 Modified Hoagland solution, buffered at pH 6.5 with $8 \mathrm{mM}$ phosphate buffer and a conductivity between 1.5 and $1.6 \mathrm{mS} \mathrm{cm}^{-1}$ (no extra salts were added). Iron complex in 1/2 Modified Hoagland solution was diethylenetraiminepentaacetic acid ferric sodium complex (Dissolvine D-Fe-11, AKZO NOBEL Functional Chemicals bv, Herkenbosch, the Netherlands). From day 1 through day 216 the catholyte was demineralized water buffered with $8 \mathrm{mM}$ phosphate buffer (pH 6.5). From day 217 through day 250 the catholyte solution was $50 \mathrm{mM}$ potassium ferricyanide $\left(\mathrm{K}_{3} \mathrm{FeCN}_{6}\right)$ solution, buffered with $8 \mathrm{mM}$ phosphate buffer ( $\mathrm{pH} 6.5$ ).

To prevent osmotic shock for $S$. anglica and electrochemical active biofilm at the construction of the P-MFC $20 \mathrm{~g} \mathrm{~L}^{-1}$ sodium chloride and $5 \mathrm{~g} \mathrm{~L}^{-1}$ magnesium chloride was added 
to both anolyte and catholyte (anolyte $37.6 \mathrm{mS} \mathrm{cm}{ }^{-1}$, and catholyte $37.1 \mathrm{mS} \mathrm{cm}^{-1}$ ).

All P-MFCs (including blanks) were daily watered from top of anode with the anolyte at a flow rate $0.9 \mathrm{~mL} \mathrm{~min}^{-1}$ for $15 \mathrm{~min}$ in the period from day 0 through day 89 and for $30 \mathrm{~min}$ in the period from day 90 through day 250 . In the open cabinet, catholyte was replenished weekly with demineralized water. In the climate control cabinet, catholyte was refreshed on day 189. The anode was sampled weekly $(4 \mathrm{~mL})$ of the cathode the $\mathrm{pH}$ was measured weekly.

\section{Analytical techniques}

Of anode samples $\mathrm{pH}$, conductivity and of a selection of samples volatile fatty acids (VFA, C2 to C5) and chemical oxygen demand (COD) were measured.

Conductivity of anode samples was measured after diluting 50 times with demineralized water which had a conductivity of $0.8 \mu \mathrm{S} \mathrm{cm} \mathrm{cm}^{-1}$.

Anode samples were centrifuged $10 \mathrm{~min}$ at $10,000 \mathrm{rpm}$ before analysis of VFA concentration and COD concentration. VFA concentration was measured by a gas chromatography (Hewlett Packard model 5890 series 2, Agilent Technologies, Amstelveen, the Netherlands) accommodated with an AT-Aquawax-DA column (Altech) and a flame ionization detector. COD concentration was measured by a COD cuvette test (LCK314; Dr Lange, GmbH, Düsseldorf, Germany).

\section{Electrochemical characterization}

Cell potential was measured online with a data acquisition instrument (Fieldpoint modules and a personal computer with Labview software, National Instruments). Cell potential, anode potential, cathode potential, and membrane potential were measured offline with a precision multimeter (True RMS multimeter, fluke 189). Anode potential and cathode potential were measured as potential difference between current collector and a silver/silverchloride $(\mathrm{Ag} / \mathrm{AgCl})$ reference electrode (3 M KCl electrode, ProSense QiS, Oosterhout, the Netherlands, $+205 \mathrm{mV}$ vs. NHE). Membrane potential (Ter Heijne et al. 2006) was measured as difference between the $\mathrm{Ag} / \mathrm{AgCl}$ reference electrodes in anode and cathode.

The incubation period is defined as the period from start of the experiment until a current density of $100 \mathrm{~mA} \mathrm{~m}^{-2}$ is generated.

\section{General vitality of $S$. anglica}

To monitor general plant vitality, shoot density, and number of living shoots per square meter was determined weekly (Haines 1979; Linthurst and Seneca 1980). There is no significant effect of salinity, ranging from $30 \mathrm{~g} \mathrm{NaCl} \mathrm{L}^{-1}$ (seawater) to $0.6 \mathrm{~g} \mathrm{NaCl} \mathrm{L}^{-1}$ (freshwater) on above and below ground biomass production (vitality) of $S$. anglica (Huckle et al. 2000).

\section{Calculations}

To interpret anode potential, acetate degradation was used as model reaction whereas for cathode potential oxygen reduction and ferricyanide reduction were used. Relation between theoretical potential, reactants and products is given by the Nernst equation. For the anode potential:

$E_{\mathrm{Th}, \mathrm{an}}=E^{0}-\frac{R T}{n F} \ln \frac{\left[\mathrm{CH}_{3} \mathrm{COO}^{-}\right]}{\left[\mathrm{HCO}_{3}^{-}\right]^{2}\left[\mathrm{H}^{+}\right]^{9}}$

for the cathode potential:

$E_{\text {Th,cath }}=E^{0}-\frac{R T}{n F} \ln \frac{1}{\mathrm{pO}_{2}\left[\mathrm{H}^{+}\right]^{4}}$

$E_{\text {Th,cath }}=E^{0}-\frac{R T}{n F} \ln \frac{\left[\mathrm{Fe}(\mathrm{CN})_{6}^{4-}\right]}{\left[\mathrm{Fe}(\mathrm{CN})_{6}^{3-}\right]}$

where $E_{\mathrm{Th}, x}$ is the theoretical potential (V), $E^{0}$ is the standard electrode potential of the reaction $(\mathrm{V}), R$ is the universal gas constant $\left(\mathrm{J} \mathrm{K}^{-1} \mathrm{~mol}^{-1}\right), T$ is the temperature $(\mathrm{K}), n$ is the number of electrons transferred in the reaction (-), $F$ is Faraday's constant $\left(96,485 \mathrm{C} \mathrm{mol}^{-1}\right),[x]$ is the concentration of reactants or products $\left(\mathrm{mol} \mathrm{L}^{-1}\right), \mathrm{pO}_{2}$ is the partial pressure of oxygen (Pascal). The electromotive force $\left(E_{\text {emf }}\right)$ was calculated by subtracting theoretical anode potential $\left(E_{\mathrm{Th}, \text { an }}\right)$ from theoretical cathode potential ( $\left.E_{\text {Th,cath }}\right)$ (Logan et al. 2006).

$E_{\text {emf }}=E_{\text {Th,cath }}-E_{\mathrm{Th}, \text { an }}$

Measured cell potential $\left(E_{\text {cell }}\right)$ is equal to electromotive force $\left(E_{\text {emf }}\right)$ minus total potential loss which is sum of: anode overpotential $\left(\eta_{\text {an }}\right)$, cathode overpotential $\left(\eta_{\text {cath }}\right)$, and membrane potential $\left(E_{\mathrm{a}-\mathrm{c}}\right)$ (Sleutels et al. 2009a).

$E_{\text {cell }}=E_{\text {emf }}-\eta_{\text {an }}-\eta_{\text {cath }}-E_{\text {a }-\mathrm{c}}$

Anode overpotential was defined as measured anode potential $\left(E_{\text {an }}\right)$ minus theoretical anode potential $\left(E_{\text {an,calc }}\right)$. Cathode overpotential was defined as theoretical cathode potential $\left(E_{\text {cath,calc }}\right)$ minus measured cathode potential $\left(E_{\text {cath }}\right)$ (Sleutels et al. 2009a).

$\eta_{\text {an }}=E_{\text {an }}-E_{\text {an,calc }} \quad \eta_{\text {cath }}=E_{\text {cath,calc }}-E_{\text {cath }}$

It is not possible to determine the theoretical anode potential $\left(E_{\text {an,calc }}\right)$ because of diversity of rhizodeposits. 
Diversity in rhizodeposits will result in a mixed potential in the anode compartment. Because of the large specific surface area of graphite granules in the anode current density was low. From Ter Heijne et al. (2008) can be deduced that low current densities result in an anode potential close to theoretical anode potential, hence a low anode overpotential.

Membrane potential $\left(E_{\mathrm{a}-\mathrm{c}}\right)$ consists of: (1) $\mathrm{pH}$ gradient loss $\left(E_{\Delta \mathrm{pH}}\right),(2)$ ionic loss $\left(E_{\text {ionic }}\right)$, and (3) transport loss $\left(E_{\mathrm{T}}\right)$ (Sleutels et al. 2009a). pH gradient loss is potential loss due to $\mathrm{pH}$ difference between anode and cathode $\left(E_{\Delta \mathrm{pH}}\right)$ and was calculated according to (Sleutels et al. 2009a).

$E_{\Delta \mathrm{pH}}=\frac{R T}{F} \ln \left(10^{\left(\mathrm{pH}_{\mathrm{cath}}-\mathrm{pH}_{\mathrm{an}}\right)}\right)$

Where $E_{\Delta \mathrm{pH}}$ is $\mathrm{pH}$ gradient loss $(\mathrm{V}), \mathrm{pH}_{\text {cath }}$ is $\mathrm{pH}$ in the cathode, and $\mathrm{pH}_{\mathrm{an}}$ is $\mathrm{pH}$ in the anode.

Ionic loss is potential loss due to ohmic resistance in the anolyte $\left(E_{\text {ionic }}\right)$ and was calculated according to (Ter Heijne et al. 2006).

$E_{\mathrm{ionic}}=i\left(\frac{d_{\mathrm{an}}}{\sigma_{\mathrm{an}}}\right)$

Where $E_{\text {ionic }}$ is ionic loss in anolyte $(\mathrm{V}), i$ is current density $\left(\mathrm{A} \mathrm{m}^{-2}\right), d_{\mathrm{an}}$ is distance between membrane and reference electrode $(\mathrm{m})$, and $\sigma_{\text {an }}$ is conductivity of the anode compartment $\left(\mathrm{S} \mathrm{m}^{-1}\right)$. Ionic loss in the catholyte was assumed zero due to relative small distance between membrane and reference electrode in the cathode compartment compared to the anode compartment.

Transport loss is potential loss due to ion transport in the anolyte and through the membrane was calculated by subtracting $\mathrm{pH}$ gradient loss $\left(E_{\Delta \mathrm{pH}}\right)$ and ionic loss $\left(E_{\text {ionic }}\right)$ from membrane potential $\left(E_{\mathrm{a}-\mathrm{c}}\right)$ (Sleutels et al. 2009a).

$E_{\mathrm{T}}=E_{\mathrm{a}-\mathrm{c}}-E_{\Delta \mathrm{pH}}-E_{\text {ionic }}$

To compare partial potential losses at different current densities, partial resistances were calculated by dividing the different potential loss by current density at that given time.

\section{Results}

Long-term electricity generation

Results showed that long-term electricity generation by $S$. anglica in a P-MFC is achievable without being lethal to the plant. The incubation period lasted 92 days for P-MFC1 and 126 for P-MFC2. After incubation P-MFC1 generated electricity 119 out of 167 days and P-MFC2 107 out of 125 days. Figure 1 shows generated current density from

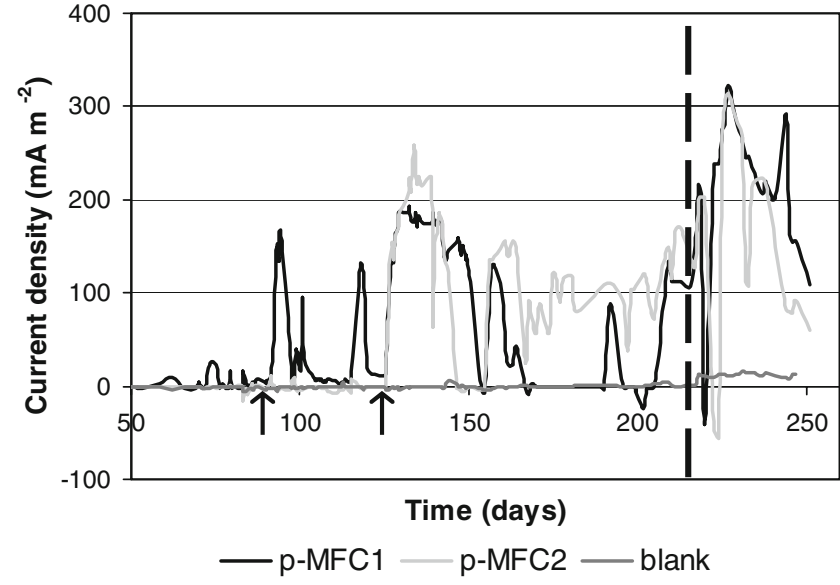

Fig. 1 Current density vs. time of P-MFC1, P-MFC2 and one blank from day 50 through day 250. Arrows indicate incubation period of $\mathrm{P}-$ MFC1 and P-MFC2. The dotted line shows change of oxygen reduction at the cathode into ferricyanide reduction at the cathode

day 50 until day 251 (end of the experiment) of P-MFC1, P-MFC2, and a blank.

In the period of oxygen reduction (day 0 through day 217), P-MFC1 generated current for 86 days with an average current density of $84 \pm 70 \mathrm{~mA} \mathrm{~m}^{-2}$ (load of $1,000 \Omega$ ), resulting in an average power density of $10 \pm 12 \mathrm{~mW} \mathrm{~m}^{-2}$ and a total energy production of $79 \mathrm{~J}$. P-MFC2 generated current for 78 days with an average current density of $141 \pm$ $52 \mathrm{~mA} \mathrm{~m}^{-2}$ (load of $1,000 \Omega$ ), resulting in an average power density $22 \pm 14 \mathrm{~mW} \mathrm{~m}^{-2}$ and a total energy production of $119 \mathrm{~J}$.

In the period of ferricyanide reduction (day 217 through day 250), P-MFC1 generated current for 33 days with an average current density of $214 \pm 78 \mathrm{~mA} \mathrm{~m}^{-2}$ (load of $1,000 \Omega$ ), resulting in an average power density of $50 \pm$ $25 \mathrm{~mW} / \mathrm{m}^{2}$ and a total energy production of $139 \mathrm{~J}$. P-MFC2 generated current for 29 days with an average current density of $195 \pm 84 \mathrm{~mA} \mathrm{~m}^{-2}$ (load of 1,000 $\Omega$ ), resulting in an average power density $42 \pm 31 \mathrm{~mW} \mathrm{~m}^{-2}$ and a total energy production of $89 \mathrm{~J}$. Blanks generated no significant current and averaged $-0.3 \pm 3.8 \mathrm{~mA} \mathrm{~m}^{-2}$ for oxygen reduction and $12 \pm 2 \mathrm{~mA} \mathrm{~m}^{-2}$ for ferricyanide reduction.

In the period of oxygen reduction maximum power output was $79 \mathrm{mWm}^{-2}$ at day 133 determined by polarization (data not shown). In the period of ferricyanide reduction

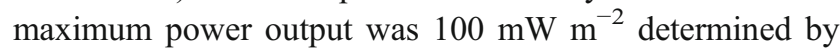
the maximum cell potential. To our knowledge, this is the highest reported power output for a P-MFC.

COD and VFA concentration in the anode

COD concentration increased from of $66 \mathrm{mg} \mathrm{L}^{-1}$ in the anode of both the P-MFCs at start of the experiment to an average COD concentration of $203 \pm 83 \mathrm{mg} \mathrm{L}^{-1}$ in the 
anode of P-MFC1 and $163 \pm 83 \mathrm{mg} \mathrm{L}^{-1}$ in the anode of PMFC2. In the blanks average COD concentration was $50 \pm$ $20 \mathrm{mg} \mathrm{L}^{-1}$, which originated from the nonbiodegradable iron complex in the $1 / 2$ Hoagland solution. Difference between COD concentration in blanks and P-MFCs indicated rhizodeposition of COD by plant roots.

VFA concentration in the anode of both P-MFCs was around detection limit $\left(2 \mathrm{mg} \mathrm{L}^{-1}\right)$. When current was generated $50 \%$ of VFA samples were below detection limit, average concentration was $1.3 \pm 1.2 \mathrm{mg} \mathrm{L}^{-1}$ (this included samples below detection limit). When no current was generated $46 \%$ of samples were below detection limit, average concentration was $2.9 \pm 3.1 \mathrm{mg} \mathrm{L}^{-1}$ (this included samples below detection limit).

$\mathrm{pH}$ in the bio-anode and cathode

The $\mathrm{pH}$ in the anode of P-MFC1 and P-MFC2 varied from 5.2 and 7.3. The $\mathrm{pH}$ in the cathode varied from 6.49.1 for P-MFC1, and from 6.5-9.0 for P-MFC2. When current was generated during oxygen reduction, the $\mathrm{pH}$ in the anode decreased from 6.9 to 6.5 for P-MFC 1 and from 6.9 to 5.3 for P-MFC2. When current was generated during cathodic ferricyanide reduction, the $\mathrm{pH}$ in the anode decreased from 6.5 to 5.2. for P-MFC 1 and from 5.3 to 5.2 for P-MFC2.

Conductivity of the anolyte

Conductivity of the anolyte decreased gradually with time from 46.7 to $4.9 \mathrm{mS} \mathrm{cm}^{-1}$ for P-MFC1 and from 56.8 to $3.1 \mathrm{mS} \mathrm{cm}{ }^{-1}$ for P-MFC2, due to watering with $1 / 2$ Hoagland solution which had a conductivity of 1.5 to $1.6 \mathrm{mS} \mathrm{cm}{ }^{-1}$.

\section{General vitality of $S$. anglica}

General vitality of P-MFC1 increased until day 210 , the number of stems increased from two to ten for P-MFC1. General vitality of P-MFC2 increased until day 222, the number of stems increased from two to seven.

At the end of the experiment the vitality of both P-MFC1 and P-MFC2 decreased. The number of living stems of PMFC1 decreased from ten to eight from day 210 through 245. The number of living stems of P-MFC2 decreased from seven to six from day 222 through 245

Cell, anode, and cathode potential versus time

Both P-MFCs showed fluctuations in cell potential, anode potential, cathode potential, and membrane potential. Figure 2 shows cell potential $\left(E_{\text {cell }}\right)$, anode potential $\left(E_{\text {an }}\right)$, cathode potential $\left(E_{\text {cath }}\right)$, and potential across the membrane

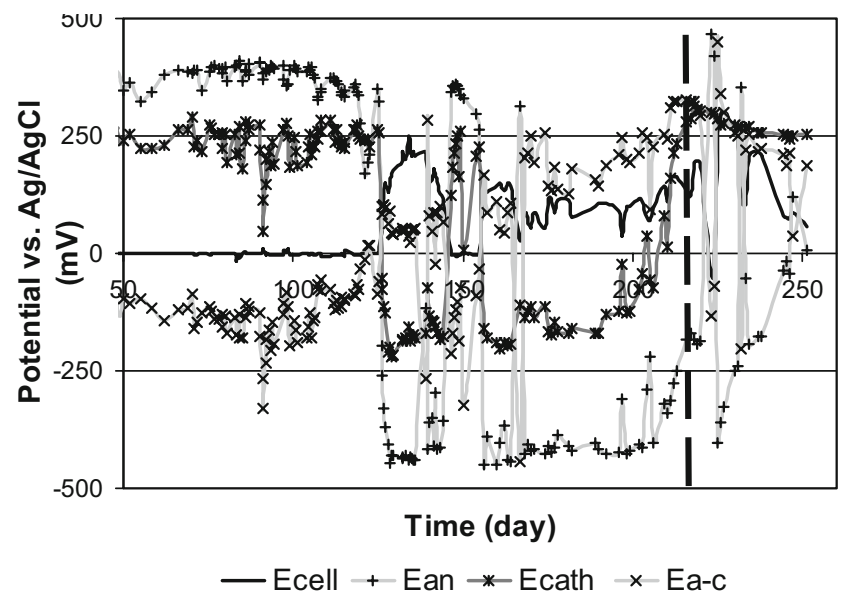

Fig. 2 Cell potential $\left(E_{\text {cell }}\right)$, anode potential $\left(E_{\text {an }}\right)$, cathode potential $\left(E_{\text {cath }}\right)$, and membrane potential $\left(E_{\mathrm{a}-\mathrm{c}}\right)$ vs. time of P-MFC2, from day 50 through day 250. The dotted line shows change of oxygen reduction at the cathode into ferricyanide reduction at the cathode

$\left(E_{\mathrm{a}-\mathrm{c}}\right)$ from day 50 through day 250 (P-MFC1 is not shown because the same trend was observed). In the incubation period of P-MFC2, anode potential and cathode potential were relatively stable with anode potential between 300 to $400 \mathrm{mV}$ (vs. $\mathrm{Ag} / \mathrm{AgCl}$ ) and cathode potential between 200 to $300 \mathrm{mV}$ (vs. $\mathrm{Ag} / \mathrm{AgCl}$ ). The potential across the membrane was negative and appeared to follow fluctuations in cathode potential. After incubation period of P-MFC2, 125 days, anode potential and cathode potential were variable over long periods of time, resulting in a variable cell potential. The anode potential of P-MFC2 varied between 465 and $-447 \mathrm{mV}$ (vs. $\mathrm{Ag} / \mathrm{AgCl}$ ). When current was generated anode potential was below cathode potential and the potential across the membrane became positive.

The change to ferricyanide reduction at day 217 increased cathode potential of P-MFC2 to $325 \mathrm{mV}$ after which it gradually decreased to $250 \mathrm{mV}$. Cell potential and anode potential of P-MFC2 showed large fluctuations from day 217 through day 225. After day 225, anode potential gradually increased from -402 to $121 \mathrm{mV}$ (day 247) with a large fluctuation at day 232. From day 225 through day 227 cell potential increased, to $302 \mathrm{mV}$ after day 227 cell potential gradually decreased to $57 \mathrm{mV}$.

Potential losses and partial resistances

Figure $3 \mathrm{a}$ and $\mathrm{b}$ show partial internal resistances and external resistance of P-MFC1 (a) and P-MFC2 (b). Figure $3 \mathrm{c}$ and $\mathrm{d}$ show partial potential losses and cell potential of P-MFC1 (c) and P-MFC2 (d). In the period of oxygen reduction, the major potential loss was cathode overpotential followed by transport potential loss. In the period of ferricyanide reduction, cathode overpotential 

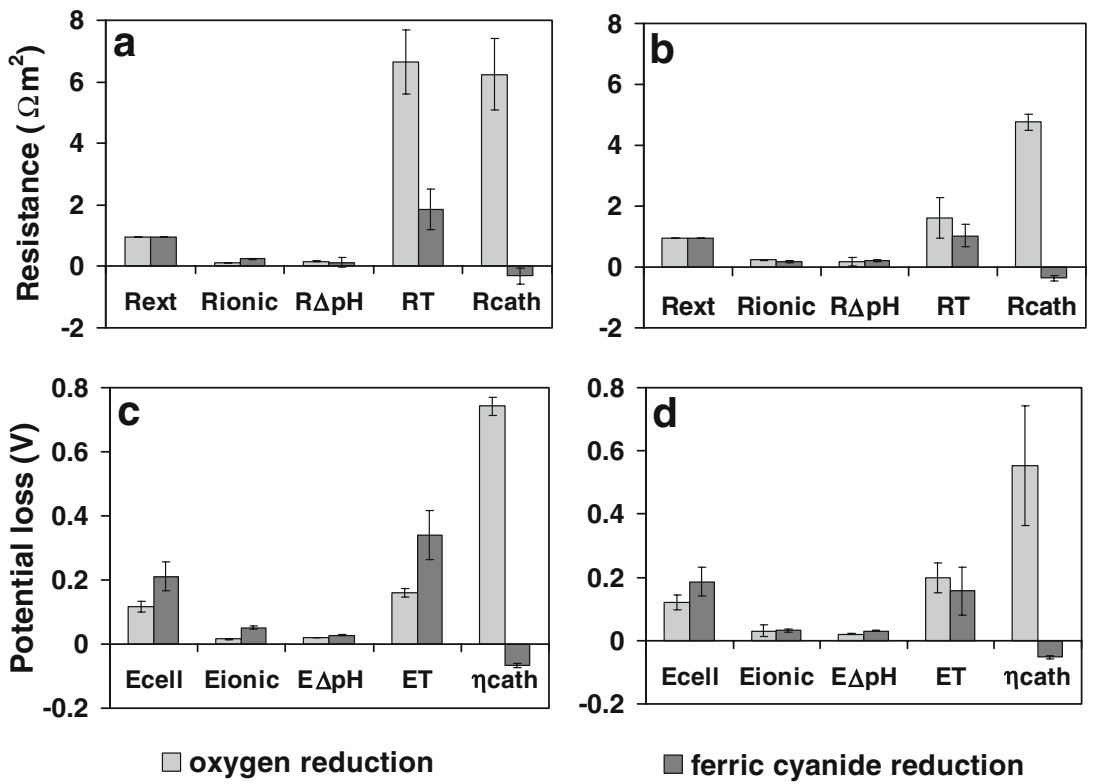

Fig. 3 a, b Average partial resistances $\left(\Omega \mathrm{m}^{2}\right)$ of days 196, 202, 209, and 216 for oxygen reduction, and days 230, 237, and 245 for ferric cyanide reduction of P-MFC1 (a) and P-MFC2 (b). Partial resistances are: external resistance (Rext) ionic resistance (Rionic), $\mathrm{pH}$ gradient resistance $(R \Delta p H)$, transport resistance $(R T)$, and cathode overpotential resistance (Rcath), calculated by dividing potential losses with produced current density. Current density defined as current per

decreased as expected, major potential loss was transport loss followed by ionic loss.

\section{Discussion}

Long-term electricity generation

S. anglica was able to live in a P-MFC for up to 167 days after incubation period and generate current up to119 days (P-MFC1). The 119 days of current generation was an increase of $175 \%$ compared to the current generation period of Strik et al. (2008). Sediment P-MFCs with rice plants of De Schamphelaire et al. (2008) and Kaku et al. (2008) produced electricity for comparable time periods. However, sediment P-MFC had lower power densities $33 \mathrm{~mW} \mathrm{~m}^{-2}$ (De Schamphelaire et al. 2008) and $6 \mathrm{~mW} \mathrm{~m}^{-2}$ (Kaku et al. 2008), compared to $79 \mathrm{~mW} \mathrm{~m}^{-2}$ for cathodic oxygen reduction in this study.

No Michaelis-Menten relation between rhizodeposits measured as COD and current

The average COD concentration in the anode of both PMFCs was three to four times higher than COD concentration in blanks; this indicated that there was rhizodeposition of COD.

geometric surface area of the anode. c, $\mathbf{d}$ Average partial potentials (V) of days 196, 202, 209, and 216 for oxygen reduction, and days 230, 237, and 245 for ferric cyanide reduction of P-MFC1 (c) and P-MFC2 (d). Partial potential are: cell potential (Ecell), ionic loss (Eionic), $\mathrm{pH}$ gradient loss $(E \Delta p H)$, and transport loss $(E T)$ and cathode overpotential ( $\eta$ cath) of P-MFC1 (c) and P-MFC2 (d)

In sediment P-MFC of De Schamphelaire et al. (2008) the relation between COD and current generation was Michaelis-Menten like. In this research there was no clear relation between COD concentration and current generation. This could be caused by: (1) the COD concentration did not represent substrate for electrochemically active bacteria, (2) saturation of electrochemically active bacteria with substrate, or (3) limitation by external resistance. Saturation of electrochemically active bacteria with substrate was improbable because the half saturation constant has to be small compared to substrate concentration. Half saturation constants of electrochemically active bacteria for different substrates vary from 111 to $725 \mathrm{mg} \mathrm{L}^{-1}$ (Catal et al. 2008) which is in same order as even lower limits of COD concentration in the anode, hence there was probably no substrate saturation. Limitation of current generation by external resistance was improbable because of high anode potential $(-221 \pm 275 \mathrm{mV})$ compared to open cell potential $(-369 \pm 97 \mathrm{mV})$. Furthermore, the ratio between the external resistance and internal resistance was 1.5 which indicated that the external resistance was relatively small.

Electricity generation limited by VFA in the anode

It is improbable that COD concentration in the anode limited current generation as the average COD concentration is in the same range of the half saturation constants 
(see previous paragraph). However, current generation may be limited by formation of VFA from biodegradable COD. In anoxic environments-such as the anode compartment of the P-MFC-biodegradable organic compounds are degraded via formation of VFAs (Stams 1994). Low concentrations of VFAs in the anode in combination with relatively high COD concentration in the anode indicated that VFA consumption was faster than VFA formation by degradation of biodegradable COD. In other words, current generation could be limited by conversion of biodegradable COD into VFAs. However, it is not possible to validate the assumption that COD in the anode was biodegradable, therefore, rhizodeposition of biodegradable COD could also have limited current generation. However, this is improbable because biodegradable organic compounds make up a large part of rhizodeposits (Farrar et al. 2003).

Acidification of anode compartment as a result of electricity generation

The production of protons by electricity generation can only result in a decrease of $\mathrm{pH}$ when proton production exceeds acid buffer capacity of the anode. The 1/2 Hoagland solution was able to buffer $4 \mathrm{mM}$ of acid. Assumed that $20 \%(27 \mathrm{~mL})$ of anolyte was refreshed every day, there was an acid buffer capacity in the anode of $0.108 \mathrm{mmol}$ protons per day. Therefore, to saturate the acid buffer capacity, $0.108 \mathrm{mmol}$ of protons had to be produced per day. When electricity was generated there was an average proton production $0.13 \pm 0.08 \mathrm{mmol}$ per day, based on stoichiometric ratio of acetate degradation. The average proton production exceeded acid buffer capacity, hence acidification of the anode was the result of electricity generation. Acidification of the anode was expected because in conventional microbial fuel cells the anode acidifies as well due to electricity generation (Rozendal et al. 2006).

Fluctuations in anode potential induced by dynamics of root development

Rhizodeposits consist of a large range of organic compounds (Farrar et al. 2003), therefore there was probably a mixed potential in the anode. Mixed potential is the average potential of simultaneous reactions of different redox couples or simultaneous oxidation of different organic compounds. Amount and speciation of rhizodeposits is related to the physiological state of individual root and changes with the life cycle of the root (Neuman and Römheld 2007). Without doubt there were changes in life cycle of the root which resulted in fluctuation in amount and speciation of rhizodeposits. Fluctuations in amount and speciation of rhizodeposits probably resulted in changes in flux of rhizodeposition and/or rhizodeposition of different organic compounds and therefore fluctuations in anode potential and as a consequence cell potential. Furthermore, $S$. anglica is able to transport a substantial amount of oxygen to their roots via the aerenchyma (Maricle and Lee 2002) which results in oxic microzone of up to $2.5 \mathrm{~mm}$ around roots due to an oxygen flux from roots into the rhizosphere (Holmer et al. 2002). Change in life cycle of the root results in change of metabolic consumption of oxygen by the root cells. Change of metabolic consumption result in a change of oxygen concentration in root cells and could therefore result in fluctuations in oxygen flux from the roots into the rhizosphere. Fluctuations in oxygen flux into the rhizosphere could result in fluctuations in the anode potential and as a consequence cell potential.

Furthermore, activity of electrochemically active bacteria which influenced the anode potential is also be affected by: fluctuations in speciation of substrate (Rabaey and Verstraete 2005), fluctuation in the anode potential (Aelterman et al. 2008), and oxygen in the anode compartment (Harnisch and Schröder 2009). However, it is beyond the scope of this research to fully determine the mechanisms which caused the anode potential to fluctuate.

Increase in current generation after decrease of cathode overpotential

In the period of oxygen reduction the current generation was limited by the VFA concentration. It is therefore surprising that the period of ferric cyanide reduction resulted not only in higher potential but also in a higher current generation. This higher current generation can be explained by the increase of the anode potential that occurred after change to ferric cyanide reduction at the cathode. Anode potential increase can lead to (1) higher activity of electrochemically active bacteria (Aelterman et al. 2008) or (2) higher coulombic efficiency (Sleutels et al. 2009b).

The activity of electrochemical active bacteria is affected by anode potential Aelterman et al. (2008) found an optimal anode potential of $-200 \mathrm{mV}$ (vs. Ag/ $\mathrm{AgCl}$ ). Therefore, increase of anode potential from -425 to $125 \mathrm{mV}$ (vs. $\mathrm{Ag} / \mathrm{AgCl}$ ) could increase current generation (Fig. 2, day 227 through day 250). Furthermore, the activity of electrochemically active bacteria could be limited by flux of biodegradable and bioavailable rhizodeposits. The flux of biodegradable and bioavailable rhizodeposits could have increased because of a decrease in vitality of $S$. anglica. A decrease in vitality of $S$. anglica could have resulted in an increase of cell membrane permeability of roots and therefore an increase in flux of biodegradable and bioavailable rhizodeposits hence an increased activity of electrochemically active bacteria and thus higher current. 
Sleutels et al. (2009b) found that an increase in current density results in an increase of coulombic efficiency because of improvement of competitive advantage of electrochemically active bacteria over methanogens. However, our data did not allow to point out the exact cause of increase of current generation after the decrease in cathode overpotential.

Transport loss is main component of membrane potential loss

To fulfill the requirement of electroneutrality, negative charge transfer due to current generation is balanced by cation transport through the membrane. Anion transport could be neglected because a cation exchange membrane was used. Because there was no forced convection through the membrane transport of a specific cation through the membrane was sum of diffusion and migration. Diffusion is driven by concentration gradient over the membrane; migration is driven by electrostatic force over the membrane which results in transport potential loss. Transport of cations other than protons result in a concentration gradient opposite to the electrostatic force (Harnisch and Schröder 2009). Therefore, to fulfill electroneutrality, a large electrostatic force is needed because it needs to overcome the membrane resistance as well as the concentration gradients. The large electrostatic force results in a large membrane potential loss and therefore a large transport loss.

Contribution of proton transport to charge transfer was probably negligible due to low proton concentration (about $10^{-5} \mathrm{M}$ in the anolyte) compared to potassium and calcium concentration (K $0.015 \mathrm{M}$ and $\mathrm{Ca}^{2+} 0.002 \mathrm{M}$ in medium). Proton transport could also be facilitated by phosphate buffer because of a concentration gradient of $\mathrm{H}_{2} \mathrm{PO}_{4}{ }^{-}$to the membrane (Fan et al. 2007). However, facilitated proton transfer was improbable because diffusion of $\mathrm{H}_{2} \mathrm{PO}_{4}{ }^{-}$to the membrane was small due to the graphite bed in the anode compartment which made diffusion distance large. Furthermore, the negative charge on the membrane surface repelled $\mathrm{H}_{2} \mathrm{PO}_{4}^{-}$. It is important to realize that even when protons were transported a large electrostatic force is needed fulfill electroneutrality because diffusion will be small due to the small concentration gradient of protons. Furthermore, a larger proton concentration gradient would not result in a lower membrane potential loss. A large proton gradient would give a high diffusion flux which eliminates the need of an additional electrostatic force for migration. However, this large proton gradient leads to an additional $\mathrm{pH}$ gradient loss, counteracting the decrease in electrostatic force needed for migration. Overall this would not lead to a substantial decrease of membrane potential loss.
Acknowledgments This research was funded by Senternovem, the Dutch governmental agency for sustainability and innovation from the Ministry of Economic Affairs (grant no. EOSLT06020) and supported by Nuon. The authors like to thank Kanjana Tuantet for executing part of the experimental work and Jan Snel for his expertise regarding plants. We also thank an unknown reviewer for very valuable comments that greatly contributed to improving the quality of the manuscript.

Open Access This article is distributed under the terms of the Creative Commons Attribution Noncommercial License which permits any noncommercial use, distribution, and reproduction in any medium, provided the original author(s) and source are credited.

\section{References}

Aelterman P, Freguia S, Keller J, Verstraete W, Rabaey K (2008) The anode potential regulates bacterial activity in microbial fuel cells. Appl Microbiol Biotechnol 78:409-418

Catal T, Li K, Bermek H, Liu H (2008) Electricity production from twelve monosaccharides using microbial fuel cells. J Power Sources 175:196-200

De Schamphelaire L, Van Den Bossche L, Hai SD, Höfte M, Boon N, Rabaey K, Verstraete W (2008) Microbial fuel cells generating electricity from rhizodeposits of rice plants. Environ Sci Technol 42:3053-3058

Fan Y, Hu H, Liu H (2007) Sustainable power generation in microbial fuel cells using bicarbonate buffer and proton transfer mechanisms. Environ Sci Technol 41:8154-8158

Farrar J, Hawes M, Jones D, Lindow S (2003) How roots control the flux of carbon to the rhizosphere. Ecology 84:827-837

Galvani A (2007) The challenge of the food sufficiency through salt tolerant crops. Rev Environ Biotechnol 6:3-16

Gray AJ, Marshall DF, Raybould AF (1991) A century of evolution in Spartina anglica. In: Begon M, Fitter A, MacFadyen A (eds) Advances in ecological research volume 21. Academic, London, pp 1-62

Haines EB (1979) Growth dynamics of cordgrass, Spartina alterniflora loisel., on control and sewage sludge fertilized plots in a Georgia salt marsh. Estuaries Coasts 2:50-53

Harnisch F, Schröder U (2009) Selectivity versus mobility: separation of anode and cathode in microbial bioelectrochemical systems. ChemSusChem 2:921-926

Holmer M, Gribsholt B, Kristensen E (2002) Effects of sea level rise on growth of Spartina anglica and oxygen dynamics in rhizosphere and salt marsh sediments. Mar Ecol Prog 225:197-204

Huckle JM, Potter JA, Marrs RH (2000) Influence of environmental factors on the growth and interactions between salt marsh plants: effects of salinity, sediment and waterlogging. J Ecol 88:492-505

Kaku N, Yonezawa N, Kodama Y, Watanabe K (2008) Plant/microbe cooperation for electricity generation in a rice paddy field. Appl Microbiol Biotechnol 79:43-49

Linthurst RA, Seneca ED (1980) The effects of standing water and drainage potential on the Spartina alterniflora-substrate complex in a North Carolina salt marsh. Estuar Coast Mar Sci $11: 41-52$

Logan BE, Hamelers B, Rozendal R, Schröder U, Keller J, Freguia S, Aelterman P, Verstraete W, Rabaey K (2006) Microbial fuel cells: methodology and technology. Environ Sci Technol 40:51815192

Maricle BR, Lee RW (2002) Aerenchyma development and oxygen transport in the estuarine cordgrasses Spartina alterniflora and Spartina anglica. Aquat Bot 74:109-120 
Neuman G, Römheld V (2007) The release of root exudates as affected by the plant physiological status. In: Pinton R, Varanini Z, Nannipieri P (eds) The Rhizosphere: biochemistry and organic substances at the soil-plant interface. CRC, Boca Raton, pp 23-72

Pimentel D, Marklein A, Toth MA, Karpoff MN, Paul GS, McCormack R, Kyriazis J, Krueger T (2009) Food versus biofuels: environmental and economic costs. Hum Ecol 37:1-12

Rabaey K, Verstraete W (2005) Microbial fuel cells: novel biotechnology for energy generation. Trends Biotechnol 23:291-298

Rozendal RA, Hamelers HVM, Buisman CJN (2006) Effects of membrane cation transport on $\mathrm{pH}$ and microbial fuel cell performance. Environ Sci Technol 40:5206-5211

Sleutels THJA, Hamelers HVM, Rozendal RA, Buisman CJN (2009a) Ion transport resistance in microbial electrolysis cells with anion and cation exchange membranes. Int J Hydrogen Energy 34:3612-3620

Sleutels THJA, Lodder R, Hamelers HVM, Buisman CJN (2009b) Improved performance of porous bio-anodes in microbial electrolysis cells by enhancing mass and charge transport. Int $\mathrm{J}$ Hydrogen Energy. doi:10.1016/j.ijhydene.2009.09.089

Stams AJM (1994) Metabolic interactions between anaerobic bacteria in methanogenic environments. Antonie van Leeuwenhoek. Int J Gen Mol Microbiol 66:271-294

Strik DPBTB, Hamelers HVM, Snel JFH, Buisman CJN (2008) Green electricity production with living plants and bacteria in a fuel cell. Int J Energy Res 32:870-876

Ter Heijne A, Hamelers HVM, De Wilde V, Rozendal RA, Buisman CJN (2006) A bipolar membrane combined with ferric iron reduction as an efficient cathode system in microbial fuel cells. Environ Sci Technol 40:5200-5205

Ter Heijne A, Hamelers HVM, Saakes M, Buisman CJN (2008) Performance of non porous graphite and titanium-based anodes in microbial fuel cells. Electrochim Acta 53:5697-5703

von Witzke H (2008) Agriculture, world food security, bio-energy and climate change: some inconvenient facts. Q J Int Agric 47:1-4 